\title{
Retraction Note to: High systemic levels of the cytokine-inducing HMGB1 isoform secreted in severe macrophage activation syndrome
}

\author{
Karin Palmblad ${ }^{1 * \dagger}$, Hanna Schierbeck $^{1 \dagger}$, Erik Sundberg ${ }^{1}$, Anna-Carin Horne, Helena Erlandsson Harris ${ }^{2}$, \\ Jan-Inge Henter ${ }^{3}$, Daniel J. Antoine ${ }^{4}$ and Ulf Andersson' ${ }^{1}$
}

\section{Retraction Note to: \\ Mol Med (2014) 20:538-547 \\ https://doi.org/10.2119/molmed.2014.00183}

The Editors-in-Chief have retracted this article (Palmblad et al. 2014) following an investigation by the University of Liverpool. The investigation concluded, based on the circumstances described below, that the data obtained by mass-spectrometry presented in Figs. 2-5 are likely to be fraudulent and should not be relied upon. The investigation found no evidence that this mass-spectrometry was carried out on any University of Liverpool instrumentation from systematic examination of equipment logs. This does not exclude the fact that the mass-spectrometry may have been undertaken at another research center. However, they found no evidence that the mass-spectrometry was performed anywhere else or any financial audit trail to indicate that instrument time was paid for elsewhere. In addition to this, the mass-spectrometry technique to quantify HMGB-1 isoforms by mass-spectrometry has been unable to be reproduced at the Liverpool laboratories using either the supplied protocol or through adaptation of the protocols. Similar data in other publications

The original article can be found online at https://doi.org/10.2119/molme d.2014.00183.

*Correspondence: Karin.Palmblad@ki.se

${ }^{\dagger}$ Karin Palmblad and Hanna Schierbeck shared first authorship

1 Unit of Pediatric Rheumatology, Department of Women's and Children's

Health, Karolinska Institutet, Karolinska University Hospital, Solna, 171

76 Stockholm, Sweden

Full list of author information is available at the end of the article investigated in this case, in which the institution has been able to assess primary data or which involve publication of assessable mass-spectra images, have demonstrated figure fabrication and fraudulent manipulation of data. The co-authors of the article were found by the investigation not to be complicit in any research misconduct, and they have been invited to resubmit a revised version of the manuscript for further peer review. More information on the university's investigation can be found on the university website (Further update on research misconduct investigation 2020).

Dr. Karin Palmblad, Dr. Anna-Carin Horne, Dr. Helena Erlandsson Harris, Dr. Jan-Inge Henter and Dr. Ulf Andersson agree to this retraction. Dr. Hanna Schierbeck and Dr. Erik Sundberg have not responded to any correspondence from the editor/publisher about this retraction.

\section{Author details \\ ${ }^{1}$ Unit of Pediatric Rheumatology, Department of Women's and Children's Health, Karolinska Institutet, Karolinska University Hospital, Solna, 171 76 Stockholm, Sweden. ${ }^{2}$ Rheumatology Unit, Department of Medicine, Karolinska Institutet, Karolinska University Hospital, Solna, Stockholm, Sweden. ${ }^{3}$ Childhood Cancer Research Unit, Department of Women's and Children's Health, Karolinska Institutet, Karolinska University Hospital, Solna, Stock- holm, Sweden. ${ }^{4}$ Medical Research Council Centre for Drug Safety Science, Department of Molecular and Clinical Pharmacology, University of Liverpool, Liverpool, UK.}

Published online: 30 December 2020

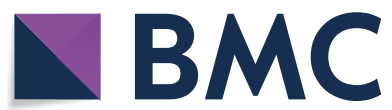

(c) The Author(s) 2020. This article is licensed under a Creative Commons Attribution 4.0 International License, which permits use, sharing, adaptation, distribution and reproduction in any medium or format, as long as you give appropriate credit to the original author(s) and the source, provide a link to the Creative Commons licence, and indicate if changes were made. The images or other third party material in this article are included in the article's Creative Commons licence, unless indicated otherwise in a credit line to the material. If material is not included in the article's Creative Commons licence and your intended use is not permitted by statutory regulation or exceeds the permitted use, you will need to obtain permission directly from the copyright holder. To view a copy of this licence, visit http://creativecommons.org/licenses/by/4.0/ 


\section{References}

Further update on research misconduct investigation, 17 August 2020. https ://news.liverpool.ac.uk/2020/08/17/further-update-on-research-misco nduct-investigation/.

Palmblad K, Schierbeck H, Sundberg E, Horne AC, Harris HE, Henter J-I, Antoine

DJ, Andersson U. High systemic levels of the cytokine-inducing HMGB1

isoform secreted in severe macrophage activation syndrome. Mol Med. 2014;20:538-47. https://doi.org/10.2119/molmed.2014.00183.

\section{Publisher's Note}

Springer Nature remains neutral with regard to jurisdictional claims in published maps and institutional affiliations.
Ready to submit your research? Choose BMC and benefit from:

- fast, convenient online submission

- thorough peer review by experienced researchers in your field

- rapid publication on acceptance

- support for research data, including large and complex data types

- gold Open Access which fosters wider collaboration and increased citations

- maximum visibility for your research: over $100 \mathrm{M}$ website views per year

At BMC, research is always in progress.

Learn more biomedcentral.com/submissions 